\title{
Determining success factors in the implementation of social accounting
}

\section{Larraitz Lazkano Ana Beraza Leire San-Jose}

ABSTRACT: The aim of this paper is to determine the success factors based on principal change driving forces when implementing social accounting into social companies, and by extension, gain an insight into the overall impact of social accounting, in other words the monetization of social value. It includes a quantitative analysis of the various effects involved in implementing social accounting in Social Economy companies: 1) improving relations with stakeholders; 2) the commitment of company employees; 3) an interest in comparing results with other companies that have also introduced social accounting; 4) networking with other organizations through social accounting. Twenty-seven percent of the social companies that apply social accounting participated in the study. It was applied at three points (prior to, immediately after and six months after applying social accounting), social accounting in order to compare expectations of perceptions regarding communication, strategy and results after implementing social accounting. The results of statistical analysis conducted by SPSS Statistics 26.0 suggest that the main reason that leads social companies to apply social accounting is to improve reputation. Likewise, they suggest that the more time passes, the greater the incidence of social accounting in communication and strategy. This study contributes to "Lewin's change theory" whereby the change project is implemented by generating greater collaborator participation through empowerment in social economy entities, where employee participation is crucial.

KEYWORDS: Social Accounting; Stakeholders; Social Economy; Social Value; Social Impact; Change Factors; Success; Change Theory.

ECONLIT CODES: M210, M410, L310, P130, P310

How to cite this article/Cómo citar este artículo: LAZKANO, L., BERAZA, A. \& SAN-JOSE, L. (2020): "Determining success factors in the implementation of social accounting", CIRIEC-España, Revista de Economía Pública, Social y Cooperativa, 100, 177-205. DOI: 10.7203/CIRIEC-E.100.18195.

Correspondence: Larraitz Lazkano, University of the Basque Country (UPV/EHU), larraitz.lazcano@ ehu.eus, ORCID ID: 0000-0002-0506-5028; Ana Beraza, University of the Basque Country (UPV/EHU), ana.beraza@ehu.eus, ORCID ID: 000-0002-5532-1800; Leire San-Jose, University of the Basque Country (UPV/EHU) and University of Huddersfield (UK), leire.sanjose@ehu.eus, ORCID ID: 0000-0003-2760-3285. 


\section{Resumen extendido}

\section{Determinación de los factores de éxito en la implementación de la contabilidad social}

\section{Objetivo}

Con el objeto de entender el impacto de la implementación de la Contabilidad Social (monetización del valor social) en compañías españolas de economía social, el objetivo de este artículo es determinar los factores de éxito basados en las principales fuerzas positivas del cambio. Para ello nos hemos basado en la teoría del cambio de Lewin, quien defiende por una parte la gestión democrática y participativa de las entidades, como lo hacen las entidades de economía social al generar mayor participación de los colaboradores mediante su empoderamiento, y por otra, la necesidad de unas fuerzas de cambio que dirijan la empresa hacia el mismo.

\section{Diseño-Metodología}

En este artículo analizaremos de manera cuantitativa los factores de éxito en la implementación de la Contabilidad Social en entidades españolas de Economía social: 1) La mejora de las relaciones con los stakeholders (grupos de interés); 2) El compromiso de los trabajadores de la compañía; 3) La curiosidad e interés de comparar los resultados con otras entidades que han realizado la Contabilidad Social; 4) El networking con otras organizaciones a través de la Contabilidad Social. Para ello, hemos realizado tres cuestionarios a 17 entidades españolas de economía social, que representan el $27 \%$ de las entidades sociales que han implementado la Contabilidad Social (modelo poliédrico) en España. El estudio se ha llevado a cabo en tres puntos de medida (antes de realizar la Contabilidad Social, justo después de su aplicación, y seis meses después) para poder así comparar las expectativas, las percepciones una vez obtenidos los resultados de la Contabilidad social y la satisfacción después de unos meses de integración de los resultados. El cuestionario se ha dividido en tres bloques: comunicación, estrategia y resultados; elementos cruciales en el cambio organizacional.

\section{Resultados}

Los resultados del análisis estadístico realizado con SPSS Statistics 26.0 sugieren que la principal razón que lleva a las entidades de Economía Social a realizar la Contabilidad Social es mejorar su reputación, como se observaba en análisis anteriores. La principal fuerza de cambio para las entidades y razón por la que inician la Contabilidad Social es la expectativa de que va a mejorar la comunicación, sobre todo con las Administraciones Públicas y la sociedad. El segundo motivo para iniciar la Contabilidad Social es la estrategia, y el tercer y último los resultados. 
La variación entre el primer cuestionario, que valora las expectativas y el segundo, que valora las percepciones una vez obtenidos los resultados del valor social es negativa en los tres bloques, siendo las expectativas mayores a las percepciones. Sin embargo, el tercer cuestionario, que representa la satisfacción de las entidades seis meses después de haber obtenido los resultados, refleja un aumento de los valores, siendo la satisfacción final mayor en resultados, seguida de la comunicación y la estrategia.

Esto denota que los factores de éxito solo se lograrán con la madurez en lo que se refiere a la implantación. Los resultados globales sugieren que cuanto más tiempo pasa, mejor es la incidencia de la Contabilidad Social en comunicación y estrategia. Esto apoya a la teoría del cambio de Lewin, quien analiza la necesidad del tiempo en el cambio.

Sin embargo, hay varios ítems donde las percepciones y la satisfacción igualan a las expectativas; por ejemplo la mejora de la reputación, la mejora del networking, el compromiso con la sociedad, la transparencia y el aprendizaje continuo.

Al analizar los resultados por segmentos observamos que por tipología de entidad, las ONGs y los Centros Especiales de Empleo son los que tienen mayores expectativas respecto a las mejoras que aporta la Contabilidad Social. Es más, la variación entre expectativa y percepción es también menor en dichas entidades.

Al hacer un análisis por tamaño, observamos que no existen variaciones significativas en los resultados de las diferentes entidades. Solo destacar que las entidades entre 11 y 100 empleados reflejan menores expectativas.

El análisis segmentado por la categoría del entrevistado que responde el cuestionario dentro de la entidad muestra que los CEOs y los financieros tienen mayores expectativas en el bloque de comunicación y los demás responsables en resultados.

\section{Conclusiones prácticas}

Este estudio tiene varias implicaciones sobre la contabilidad social para las empresas de la economía social, ya que proporciona una explicación de las fuerzas impulsoras que son necesarias para lograr un cambio exitoso al implementar la contabilidad social. Estos hallazgos pueden ayudar a la dirección de empresas pertenecientes a la economía social a enfocarse en brindar herramientas o conocimiento a través de la capacitación de los empleados en contabilidad social para integrar la contabilidad social en la mejora de la estrategia, y desarrollar planes de comunicación social justo después de la implementación de la Contabilidad Social. No obstante, la contabilidad social también ofrece a las organizaciones de la economía social la oportunidad de reconsiderar sus relaciones con los grupos de interés para mejorar su compromiso social y su impacto social. Para el personal surge una clara oportunidad de mejorar su compromiso con la empresa. Finalmente, la contabilidad social se percibe como un promotor del networking entre empresas del mismo sector, ya que ofrece la oportunidad de compartir y comparar sus resultados con otras empresas. En resumen, esas expectativas -la reputación, la mejora del impacto social, la relación con los grupos de interés y la comunicación con la administración pública y los grupos de interés- serán los prerrequisitos, entendidos como los motores que hacen exitosa la implementación de la Contabilidad Social. 


\section{Limitaciones}

Varias limitaciones de este estudio deberían quedar reflejadas. Por una parte, el limitado número de participantes. La falta de herramientas y conocimiento para integrar la contabilidad social y el largo periodo que requiere su implementación justifica la baja tasa de respuesta de este tercer cuestionario. Otra limitación es que la mayoría de las entidades que representan la muestra son fundaciones, contribuyendo probablemente a una visión sesgada de los factores de cambio, que deberá ser examinada en otro tipo de entidades. La teoría de Lewin también ha sido criticada por simplista. De la misma manera, este estudio no explica la experiencia de los involucrados. Por ello, los resultados deben interpretarse con precaución.

\section{Futuras líneas de investigación}

La investigación futura podría centrarse en una gama más amplia de empresas con una actividad productiva. También la investigación puede dirigirse a examinar más a fondo los beneficios esperados en oposición a los beneficios reales derivados de la aplicación de la contabilidad social, y esas fuerzas restrictivas para equilibrar el proceso de cambio y hacer una contribución de amplio alcance.

Palabras clave: Contabilidad Social; Economía Social; Valor Social; Impacto Social; Factores de Cambio; Éxito; Teoría del Cambio.

"Financiado por la UPV/EHU (proyectos US20/11 y PES20/10) y FESIDE. 


\section{Introduction}

The social economy movement, regulated by Law 5/2011, of March 29, is formed by 42,000 companies in Spain, and represents 10\% of Spanish GDP and 12.5\% of employment, according to data from the Spanish Social Economy Employers' Confederation (CEPES). It can be considered a rapidly-growing sector, as 29,000 companies and 190,000 new jobs have been created over the last 8 years (Chaves \& Monzón, 2018). Moreover, 80\% of the employment contracts are indefinite, despite accounting for a mere the $10 \%$ of the Spanish global economy (Spanish National Statistics Agency - INE in its Spanish initials). Consequently, the social economy, despite representing only a small part of the economy, generates stable and quality employment, contributing stability to the Spanish economy.

Social economy is integrated by social companies, which, as defined by the law mentioned above, have a specific legal format. They include cooperatives, mutual holdings, associations, foundations, social enterprises and parity institutions. They all share common values and features: the primacy of the individual and the social objective over capital; voluntary and open membership; democratic governance; the combined interests of members/users and/or the general interest; the defense and application of the principles of solidarity and responsibility; autonomous management and independence from public authorities; the reinvestment of at least the largest share of profits in sustainable development objectives, services of interest to members or of general interest (Restakis, 2006).

Consequently, social companies do have an economic activity, although their objective is morally social, and therefore measuring social value should take precedence over the measurement of economic value. The only standardized way they have to measure impact is traditional accountancy, which does not include social impact. There are many methodologies social companies could use to calculate their social value, including GRI, B Impact Assessment or the Common Good balance sheet, SROI (San-Jose, Mendizabal \& Retolaza 2020). Each measure different indicators, in different ways and with different results, and most of them are based on points rather than economic units. Ninety-eight percent of the non-financial quantitative indicators can be measured in many different ways. The enormous heterogeneity in the calculation of non-financial indicators and the variability of the results question their capacity for comparison and their reliability (Ernst \& Young [EY], 2019). As the size of this third sector grows, the demand for standardized indicators or methodologies to measure their social value and social impact also increases.

Financiado por la UPV/EHU (proyectos US20/11 y PES20/10) y FESIDE.Social accounting allows for the monetization of social value in terms that are similar to traditional accounting, but taking into consideration all actors, not only the shareholders (Retolaza et al., 2015; San-Jose \& Retolaza, 2016). Many social companies have implemented social accounting (Lazkano et al., 2019), as it is especially suitable to measure their social value, since the social impact is not measured in accordance with pre-established indicators; instead, variables are generated ad hoc for each organization based on the stakeholders affected by its activity (Etxezarreta et al., 2018). It follows the same rules and logic as if it were based on real data, and the 
results are presented in the same terms as traditional accounting, namely in monetary units and ratios. The aim of social accounting is to complement traditional accountancy. Its application is shown academically, for example using the Clade case (Lazkano \& San-Jose, 2019) or also Zabalduz S. Coop (Etxezarreta et al., 2018). These papers show not only the process and phases of the social accounting, but also its importance for social economy companies.

Although not all social economy companies apply this type of measurement to show their social contribution, the rate of companies applying social accounting is experiencing a steady upward trend. Nevertheless, to date, no analysis has been made of the impact of the actual process and results in terms of the added value social accounting generates. There is a gap in literature regarding the success of using these measurements. Despite its unquestionable theoretical interest for managers, our aim is to analyze the effect of implementing social accounting in order to improve its integration and application to companies. Change is crucial for organizations, and social companies are no exception. Social companies evolve in a space based on transparency, communication and information. Counting the social values of companies is important because it presents their social activity before society, the essence of this type of companies. Moreover, this new social system, known as social accounting, could affect their competitiveness; therefore, it is important to know how to promote and push positive factors with the aim of achieving a successful and privileged situation during the change. Those factors could allow for a successful change. We will use Lewin's theory of positive driving factors because it is an early fundamental planned change model that explains the driving forces pushing for successful change. In this sense, the research question is as follows: what are the most important change driving forces for the implementation of social accounting in the social economy?

Following Lazkano \& Beraza (2019), the main objective of this paper is to determine the principal change-emerging factors based on Lewin's Change Model theory in Spanish social companies in the three phases: before starting social accounting; once it is completed and the results have been obtained; and some time (approximately six months) after calculating their social value. In the attempt to determine the change-emerging factors that will result in the successful implementation of social accounting, we studied social companies that have calculated their social value using the Polyhedral Model (see Retolaza et al., 2016 for a full explanation). Through questionnaires dating from 2017 to 2020, we analyzed these social companies from three perspectives aligned with business management: communication, strategy and results (Spathis \& Ananiadis, 2005). SPSS 26.0 was used for the statistical analysis and a variance analysis was applied (Welch test).

On the one hand, Lewin's Change Model supports democratic institutions, as he was committed to extending democratic values in society. Social companies have democratic management and decision making models. On the other hand, Lewin's model includes forces driving change and forces restraining it. In order for change to occur, the driving force must exceed the restraining force. Driving forces are studied in this paper in order for change to occur.

We will use a significant sample of social economy organizations that have applied social accounting and with the results from a three moment questionnaire (before, immediately fol- 
lowing the application of social accounting, and six months after) we will answer the research questions. On the one hand, once again the results prove that companies within the social economy sector contribute significant value to society; and on the other hand, they identify a set of indicators that can be subsequently introduced into management. However, more importantly, we have analyzed how these initial expectations change once immersed in the calculation, as well as the impact, change-generating factors, and use of these results in the company. We will show that organizations that approach social accounting usually do so from a reputational perspective. Our analysis supports previous exploratory results (Lazkano \& Beraza, 2019), but analyze goes further and establishes that expectations are higher than the effects or perceptions, and therefore, social accounting is insufficient in order to see change driving forces in companies. It requires more than the application and obtaining of social value results. The changes through social accounting come sometime after, once it has been socialized and integrated into the company. All those forces must be taken into consideration when introducing social accounting into an organization where the aim is to secure successful and consolidated change.

The structure of this paper as follows: following the introduction, we review scientific literature and opinion, analyzing the theory that we are contributing to "Lewin's change theory". This is followed by a description of the methodology used to obtain our results. The paper ends with a discussion of the results obtained, the conclusions and implications.

\section{Background and conceptual framework}

There is an academic and social interest for establishing how business models create value for stakeholders (Freeman, 1984) and it is highlighted the importance of measuring this value (Harrison et al., 2020 specially in social economy (Velamuri, Priya, \& Vasantha ,2015). Social accounting allows to identify and quantify the distribution of value between the various stakeholders of an organization (Gray, 2002; Retolaza et al., 2016). The consolidation of the value generated for the full set of stakeholders reflects the overall value generated by the organization.

The promise of Social Accounting to achieve organizational change is possible the most relevant issue for the years to come (Broccardo \& Zicari, 2020). Regarding this purpose, Lewin's change theory had undoubtedly an enormous impact on the field of change. He believed that a field was in a continuous state of adaptation and that 'Change and constancy are relative concepts; group life is never without change, merely differences in the amount and type of change exist' (Lewin, 1947, p. 199). Lewin thinks change leads to a disruption of a stable situation. People like to keep the old situation as it is because it is safe and predictable. People are only capable of accepting change when they know what this change will bring them. 
Lewin's work was a strong moral and ethical belief in the importance of democratic institutions and democratic values in society. Lewin believed that only by strengthening democratic participation in all aspects of life and being able to resolve social conflicts. In this aspect, organizations belonging to social economy totally have a democratic participation.

To this end, Action Research draws on Lewin's work on Field Theory to identify the forces that focus on the group to which the individual belongs. It also draws on Group Dynamics to understand why group members behave in the way they do when subjected to these forces. Action Research stresses that for change to be effective; it must take place at the group level, and must be a participative and collaborative process, which involves all of those concerned (Allport, 1948; Bargal \& Bar, 1992; French \& Bell, 1984; Lewin, 1947b).

The rate of companies doing Social Accounting is increasing year by year; it is a $99 \%$ of average growth in the last ten years (2011-2019) with some peaks nearly 300\% on 2015 and 2016. Then, the need of measuring their impact grows, as well as the analysis of the impact of doing Social Accounting (Retolaza et al., 2015, 2016; San-Jose \& Retolaza, 2016; Retolaza \& San-Jose, 2018); and consequently the determinate what are the change driving forces will be the key if we want to achieve a successful implementation.

Previous literature has tried to analyze the impact of using Social Accounting. It has used a qualitative research through interviews to all social companies doing social accounting (dividing them in two groups; the ones who had not started doing social accounting but were committed to start, and the ones who had already finished) during 2018-2019 (Lazkano \& Beraza, 2019). In this study the change factors observed in social companies implementing social accounting were: 1) The improvement of the relationship with stakeholders, from being a relationship that organizations considered as good or indifferent to establishing a closer relationship where stakeholders feel important for the company; 2) The commitment of employees belonging to the company. Employees, once they know the result and the social value their organizations generate, feel proud and more committed to their company; 3) Curiosity and interest to compare results with other companies that have also done social accounting; 4) Networking with other organizations through social accounting, calculating companies in the same sector at the same time or companies that have already finished the process helping other companies that are going to start. Lazkano \& Beraza (2019) concluded that the principal reason for doing Social Accounting was a matter of reputation, but after doing it, most social companies mainly reported the results internally, giving more value to the process than to the results.

In this paper a deeper analysis of the impact of doing Social Accounting is carried in order to analyze the variation between expectations and perceptions concluded in the explanatory study through interviews. To confirm this previous phase, and to get to more concrete factors we have gone to a quantitative study through questionnaires to determine the change factors in social companies that have done social accounting.

Some studies have been conducted regarding the relation of CSR practices and its relationship with the employees' increase of identification and commitment to the organization, organizational citizenship behaviors and meaningfulness of work (Aguilera et al., 2007). How- 
ever, there is not any study, which analyses the social impact after the application of any social value measurement methodology or Social Accounting.

The variation between expectations and perceptions after the application of Social Accounting have been studied in three blocks:

1) Communication

2) Strategy

3) Results

Communication is considered as a process through which there is information exchange between individuals within organization and stakeholders, through the use of commonly accepted symbols (Monge, 2008). Lewis (1999) considers that the acceptance of the change by the members of the organization depends on the way in which the managers share the information. Lewis affirms after several studies that communication is a crucial element in organizational change.

Strategy or Strategic Planning is a dynamic process flexible enough to allow and even force modifications in plans, in order to respond to changing circumstances (Tito, 2003). It is crucial in the organizational change of social entities because it maintains the company focused on the vision, mission and social objectives.

The result measures the set of changes generated by the process. Social entities start doing Social Accounting with the expectation that some changes will occur after all, and this study measures the variation of those expectations and the perception.

\section{Methodology}

We will use the polyhedral model because it is the only system that allows the monetization of social value of the exploitation activity of a company and also, takes into consideration all the stakeholders (holistic view) (San-Jose \& Retolaza, 2016). Comparing to traditional accounting the advantages are the following: It is the most complete system, useful in all types of organizations, it calculates the social value generated for each stakeholder as well as an integral social value, it provides a visible result, and it is more homogeneous. Moreover, some many other measures could calculate based on this Social Accounting, then it permits the complementary analysis and vies, for example SROI is possible to calculate with Social Accounting data.

As we can see in the following Figure 1, many organizations have already done Social Accounting with the polyhedral model since 2011, being mostly social companies. 


\section{Figure 1. Evolution in the calculation of Social Value with the Polyhedral Model}

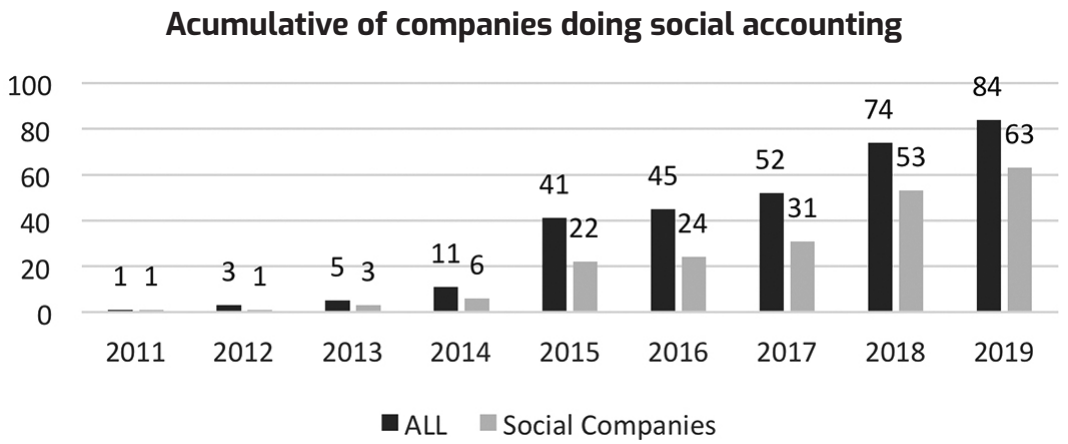

Source: Authors' own based on GEAccounting data (www.geaccounting.org).

\section{Sample}

We study Spanish social economy companies that have already applied the Social Accounting (monetizing social value) (Retolaza et al., 2016) and polyhedral model to calculate their social value in three different moments: before starting the calculation, once finished and some time after (See table1).

Lazkano \& Beraza (2019) evidenced in previous studies the need to measure the real impact and influence of Social Accounting in future researches, for which some time after the implementation of social accounting should be left. On the other hand, Lewin explains in his theory of change that the parties involved in the change must have time to assimilate it. Based on so, a third phase has been added in this research, in order to analyze the impact not only before and after it occurs, but also some time after. 
Table 1. Sample

\begin{tabular}{|c|c|c|c|c|c|}
\hline Company & Typology & Location & Questionnaire 1 & Questionnaire 2 & Questionnaire 3 \\
\hline Lantegi Batuak & Laboral insertion & Euskadi & $x$ & $x$ & $x$ \\
\hline Grupo Clade & $\begin{array}{l}\text { Cooperative } \\
\text { group }\end{array}$ & Cataluña & $x$ & $x$ & $x$ \\
\hline Cogami & Laboral insertion & Galicia & $x$ & & \\
\hline Ucan & $\begin{array}{l}\text { Cooperative } \\
\text { group }\end{array}$ & Navarra & $x$ & $x$ & $x$ \\
\hline $\begin{array}{l}\text { Acción Contra el } \\
\text { Hambre }\end{array}$ & NGO & Madrid & $x$ & $x$ & $x$ \\
\hline Som Fundació & Laboral insertion & Cataluña & $x$ & $x$ & $x$ \\
\hline Futubide & Laboral insertion & Euskadi & $x$ & $x$ & $x$ \\
\hline $\begin{array}{l}\text { Museo de la } \\
\text { Minería del País } \\
\text { Vasco }\end{array}$ & Asociation & Euskadi & $x$ & $x$ & \\
\hline Aquarium SS & Foundation & Euskadi & $x$ & $x$ & \\
\hline San Telmo & Public - S.A. & Euskadi & $x$ & $x$ & \\
\hline Artium & Foundation & Euskadi & $x$ & $x$ & \\
\hline Itsas Museum & Foundation & Euskadi & $x$ & $x$ & \\
\hline Archivo Diocesano & Foundation & Euskadi & $x$ & $x$ & \\
\hline $\begin{array}{l}\text { Museo Bellas Artes } \\
\text { Bilbao }\end{array}$ & Foundation & Euskadi & $x$ & $x$ & \\
\hline Mutualia & Mutual holding & Euskadi & $x$ & $x$ & \\
\hline Anel & $\begin{array}{l}\text { Cooperative } \\
\text { group }\end{array}$ & Navarra & $x$ & $x$ & \\
\hline Katea Legaia & Laboral insertion & Euskadi & $x$ & $x$ & $x$ \\
\hline
\end{tabular}

Regarding the population, based on data provided by GEAccounting, the total number of organizations belonging to the third sector that have implemented this specific model is 63 companies (2019 data), of which 17 entities participated in the study $(26,98 \%$ of the population). Since the study has focused on the social companies that have applied this model in 2019 , those 17 organizations represent the $100 \%$ of them. In relation to the length of time in the implementation of this method, $41.17 \%$ of the companies analyzed have been calculating the social value for more than two years, the ones which have showed a highest level of compromise implementing the method along the time, only these 7 organizations have received and answered the third questionnaire. The company that has been doing social accounting for the longest time is Lantegi Batuak, since 2011, one company since 2013, two companies since 
2015, another three since 2016 and two companies since 2018. The rest, 10 companies, they have just monetized social value for the first time. Some of the organizations that were interviewed are among the most representative of the population in their respective geographical area (e.g., ANEL, UCAN, GRUPO CLADE, COGAMI), since most of them are associations or groups of social economy companies belonging to a single or different sectors. In some cases, they are also leading companies in their sector and geographic area (e.g. Mutualia, Lantegi Batuak, Katea Legaia, Artium, Museo Bellas Artes Bilbao) (see Table 1). Since they are foundations, cooperatives, mutual societies, insertion companies, special employment centers or business groups (see Table 1), depending on the legal form of social economy company (according to Law 5/2011 on Social Economy), most types of social companies are represented in the sample1. Considering the criteria of antiquity in the implementation of the polyhedral model, typological and sectoral diversity of social economy companies, and the economic importance for their respective geographical areas, we consider the sample sufficiently representative of the population.

All the analyzed companies are organizations that belong to the social economy sector. All of them have done Social Accounting with the polyhedral model in 2019 and have answered at least one of the three questionnaires.

\section{Research Method}

A quantitative method was applied, considering the differences in the three moments. This consisted essentially of variance analysis on the means comparison of the results obtained in the three questionnaires. Specifically, a Welch test was used to determine any significant differences between the means of the three groups of responses (pre, post and post2).

In order to provide accurate information, structured questionnaires were distributed at three-measurement points (pre-implementation, immediately following implementation and post-implementation) in the frame of longitudinal research. The survey was conducted among the 17 social companies that applied social accounting in 2019. Most of them completed the first two questionnaires but only seven of returned the third questionnaire, namely only those that have been applying social accounting for more than two years. During the survey, the questionnaires were distributed, filled in and returned at three time periods by the same users.

1. Although San Telmo Museum is a Public Limited Company (PLC), since this organization share the values and specific characteristics of social economy enterprises in accordance with the section 2 of article 5 of Law 5/2011 on social economy companies, San Telmo Museum is considered a social economy company. 


\section{Table 2. Research technical file}

\begin{tabular}{|c|c|}
\hline Research Method & Quantitative Analysis \\
\hline Quantitative Technique & $\begin{array}{l}\text { Longitudinal Study in three-measurement points (pre-, just, and } \\
\text { post-implementation) }\end{array}$ \\
\hline Population & Spanish social companies that have applied social accounting \\
\hline Sample & $\begin{array}{l}17 \text { Spanish social companies that have implemented the } \\
\text { polyhedral model to calculate their social value in } 2019\end{array}$ \\
\hline Data collection technique & $\begin{array}{l}\text { Survey. Three questionnaires each company were passed and } \\
\text { collected in three-measurement points }\end{array}$ \\
\hline Data collection instrument & 7-points Likert scale questionnaire with close questions \\
\hline Data analysis technique & Analysis of variance using Welch tests by SPSS statistics 26.0 \\
\hline Duration of questionnaires & 5 min on average \\
\hline Fieldwork period & From November 2019 to July 2020 \\
\hline
\end{tabular}

Source: Authors' own.

\section{Interviewee Profile}

Most interviewees were managing directors of the companies that formed part of the sample (nine out of 17); in the remaining cases, they were merely financial directors (5 out of 17); a minority were engineering, quality, marketing and security managers. In all cases, they had a broad perspective of their organization's strategy and were able to address questions regarding social accounting implementation in their respective companies.

In order to enhance the internal validity of the study and to be able to compare responses with greater confidence, all survey respondents represent the same level of analysis.

\section{Conducting the Questionnaires}

The initial contact with the organizations was either in person or by email: whenever possible, the questionnaires were conducted in person. The average duration of each questionnaire was five minutes, and they were all scanned, recorded on Excel and analyzed with SPSS.

Before collecting each questionnaire, respondents were asked to agree to the use of their data.

Of the seventeen companies analyzed, only one completed only the first questionnaire referring to the initial situation before starting social accounting; 17 answered the first and second questionnaires, which was completed after the social accounting process; and 7 returned all three questionnaires (the third was conducted some time after the social accounting pro- 
cedure. All three questionnaires were identical, and contained three sections: communication, strategy and result. The responses were based on a Likert scale of seven options, where 1 represented total disagreement and 7 total agreement (See Annex 1).

\section{Evidence Analysis}

In this study, an analysis of variance was performed based on the Welch test. Specifically, we analyzed the mean value of each change factor (communication, strategy and results) and the mean values adopted by each of the 32 items divided into groups; one for each change factor in the three-measurement points to realize a longitudinal analysis comparing the results obtained. Afterwards, a segmented analysis was made by sector, size and position of the manager who responded to the questionnaire. We therefore conducted a segregated analysis regarding only the average responses of the two first questionnaires, as we failed to obtain sufficient responses to questionnaire 3 for a full segregation.

\section{Hypothesis}

We formulated a number of hypotheses based on the literature reviewed about previous studies which analyze the implementation of CSR using Lewin's (1951) force field model of change (Maon et al., 2009); studies into the relevance of communication in organizational change (Monge, 2008; Lewis 1999); and previous findings of the authors (Lazkano \& Beraza, 2019), where there is evidence that suggest that communication is a critical driver factor for implementing social accounting. As the authors concluded in previous studies, the principal reason that lead companies to calculate their social value was the need to present arguments before public administrations. Therefore, the first hypothesis is that communication should be the most relevant motivation for social accounting, particularly before public administrations. According to the literature reviewed about strategic factors drivers in organizational change by CSR implementation (Lenssen, 2009), the authors also evidenced in their previous study that only companies that had calculated social accounting over time had applied the results to strategy and management. Therefore, the second hypothesis is that the more time passes after the calculation of social accounting, the wider its integration into strategy.

The third hypothesis also comes from the conclusions of previous studies, where findings suggested that companies started social accounting to communicate their social value publicly, but after the calculation organizations realized that the results were more important that merely making them public. In this sense, the third hypothesis is that the results of social accounting increase in importance following their actual calculation.

Depending on the sector or type of company, a fourth hypothesis could be that companies whose purpose is closer to society have higher expectations, such as special employment centers. 


\section{Results and discussion}

The way in which a new social accounting process affects the management and social results of the social economy is of major academic interest, not only from a systematic/quantitative point of view, but also from the perspective of process and change. However, in addition to their academic value, the flow of expectations and perceptions is also of value practitioners that could consider them to increase efficiency when implementing new methodologies, measurements, or systems to improve their corporate social purpose. Overall, the results show that on average, the variation between the first and second questionnaires is negative from a previous (pre) to an intermediate phase (post). However, the mean rises in the third questionnaire, once social accounting has been integrated into the company, and which is conducted around six months after the calculations are complete (post2) (see Figure 2).

\section{Figure 2. Means of variations: pre, post and post2 long lineal analysis}

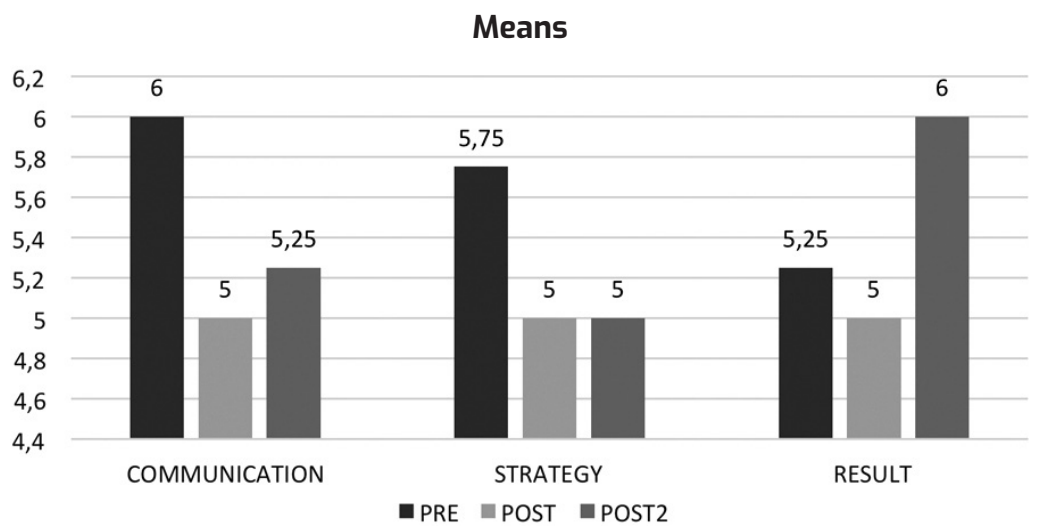

Source: Authors' own based on results from SPSS.

The findings show that companies start social accounting with a notion that it will prove particularly useful for communication, with an average score of six out of seven; especially in communication with society and reputation. This corroborates previous studies that concluded that companies start social accounting from a reputational perspective. The second reason for introducing social accounting is strategy, with a mean of five point seventy-five out of seven. In this case, company expectations regarding strategy are slightly higher than perceptions following the calculation of social accounting. The final block shows that even though entities fail to consider the potential results of social accounting, following implementation implementing it, they realize that this is in fact its principal contribution with a mean score of six out of seven. 


\section{Communication}

A closer analysis of each block reveals that there are significant differences in communication, especially in the opinions regarding communication with public administrations (C_PA), with funders (C_F) and society (C_SO). Furthermore, legitimacy before public administrations (L_PA) and society (SO_L) decreases significantly (see figure 3). A later analysis (biased by the small number of entities that have implemented it, and therefore limited) predicts that the valuations will improve significantly when it comes to public administrations (L_PA) and slightly in communication with funders (C_F) communication with society (C_SO) and social legitimacy (SO_L). However, even this result requires a greater number of responses. This denotes that the expectation created is very high; in the implementation process the complexity and difficulties of social accounting stand out, precisely because it is an internal process. Subsequently, at the end of the assessment, it increases again, thereby predicting that although there are barriers, it can be used for its original intention. This result evidences the need for improvement in communication with public administrations, but also with other stakeholders.

In terms of reputation (REPUT), the mean score shows that companies expect that social accounting will improve the company's reputation, with an average of six out of seven, which represented a very high agreement, and this score remains constant throughout all three phases. Companies therefore expect and afterwards perceive that social accounting improves company reputation, one of the principal motivating factors behind social accounting.

\section{Figure 3. Communication: means by question}

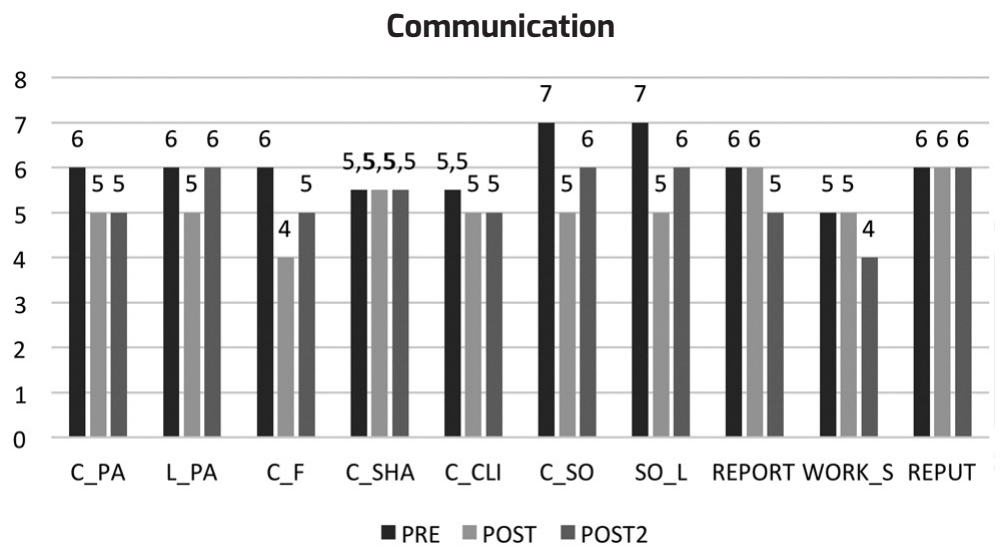

Source: Authors' own based on results from SPSS. 


\section{Strategy}

When focusing on strategy, almost all item mean scores experience a downturn in the second questionnaire (see Figure 4). This shows that during this middle phase, companies are unable to relate or apply social accounting to strategy. However, once integrated, entities become convinced that social accounting can improve the strategy, the social impact or the relation with stakeholders, as appreciated in the third questionnaire.

If we analyze by item or question, from the first to the second questionnaire, the items related with the improvement of strategy (STR), the improvement of operational management (O_M), the improvement of management quality (M_Q), the improvement of social impact (SO_I), the improvement of shared value management (SVM), the improvement of governance (GOV), the improvement of the entity's economic results (EC_R), and improvement of the relationship with the stakeholders (REL_STK) decrease. There is clear evidence of a lack of tools or knowledge to integrate or apply social accounting in order to improve strategy at this phase.

In the third questionnaire, after the integration of the results, companies realize that social accounting does improve strategy (STR), social impact (SO_I), governance (GOV) and relations with stakeholders (REL_STK). Therefore, even though the variation between expectations and perceptions is not as significant as in communication, the results evidence that companies need some time after the calculation of social accounting to apply the results to strategy improvements.

\section{Figure 4. Strategy: means by question}

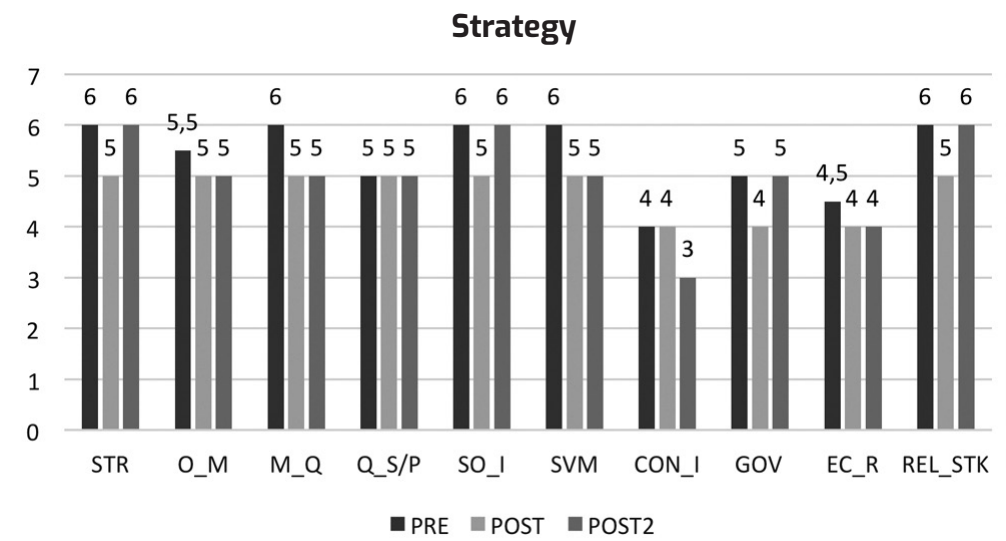

Source: Authors' own based on results from SPSS. 


\section{Results}

As for the results, expectations are lower than for communication and strategy, and the trend is not as negative as in the two previous blocks; indeed this is the only block where perceptions exceed initial expectations in the third questionnaire. Even so, the means for the responses to questions about the improvement of the knowledge of the organization (KN_0), reduction of social risk (SO_R), improvement of the purpose (PURP) and sustainability (SUST) drops from the first to the second questionnaires. The mean of the item related to networking (NET) rises from the first to the intermediate questionnaire. As observed in previous studies, companies are willing to share and compare their results with other organizations, and so networking is highly valued.

If we analyze the responses of the third questionnaire, we can observe that the mean of the item linked to the perception of the knowledge about the organization (KN_O) rises, as well as the improvement of positioning (POS), social risk reduction (SO_R), purpose (PURP) and the alignment of stakeholders' interests (INT_STK). Therefore, it is once again clear that employers need time to perceive the improvements social accounting offers.

It is worth noting that high expectations match perceptions in several questions, as in the improvement of continuous learning (C_L); workers' (WRK_M), improvement of transparency (TRNS); and the reinforcement of social commitment (SO_C).

\section{Figure 5. Result: means by question}

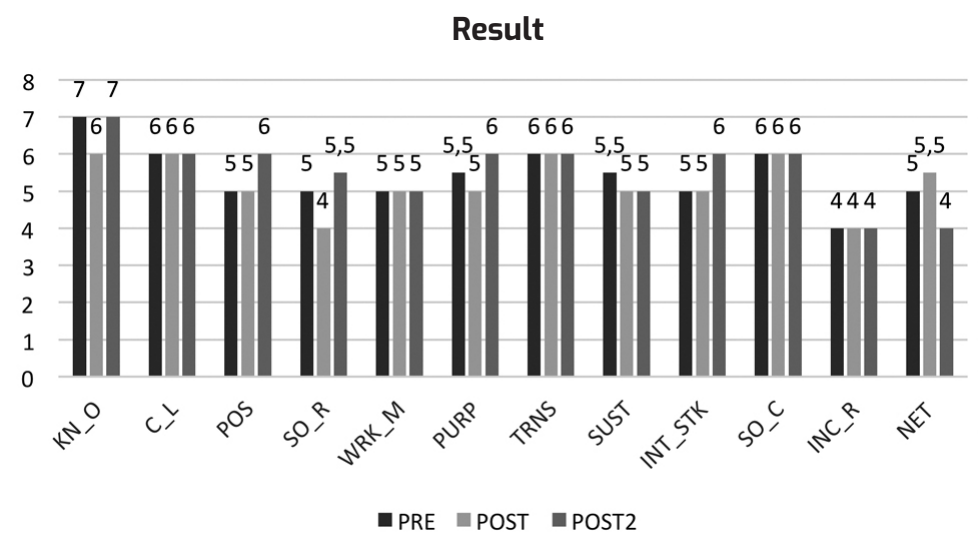

Source: Authors' own based on results from SPSS.

We have established a negative trend between the first and second questionnaires, due to the lack of integration of social accounting, especially in communication and strategy. After some time, integration and socialization of the results, the use of social accounting is wider. 
It must be noted that some questions that improve from the beginning, such as networking, whilst others reach the initial high expectations, namely the improvement of the organization's reputation, ongoing learning, transparency and the reinforcement of social commitment.

Companies start social accounting from a reputational perspective, and high expectations in terms of strategy, which are reached with time and the integration of social accounting. Furthermore, the high expectations in terms of transparency and social commitment are reached right from the start.

\section{Table 3. Statistical Analysis of Driving Forces over time}

\begin{tabular}{|c|c|c|c|c|c|c|}
\hline \multirow{2}{*}{$\begin{array}{l}\text { Driving } \\
\text { Forces }\end{array}$} & \multicolumn{3}{|c|}{$\begin{array}{c}\text { Mean } \\
\text { (deviation) }\end{array}$} & \multirow{2}{*}{$\begin{array}{c}\begin{array}{c}\text { Statistical Test } \\
\text { Welch+ }\end{array} \\
3.356\end{array}$} & \multirow{2}{*}{$\begin{array}{c}\begin{array}{c}\text { Significate } \\
\text { level }\end{array} \\
*\end{array}$} & \multirow{3}{*}{$\begin{array}{c}\begin{array}{c}\text { Null Hypothesis } \\
\text { Decision }\end{array} \\
\text { REJECTED }\end{array}$} \\
\hline & PRE & POST & 0.967 & & & \\
\hline & & POST2 & 0.356 & & & \\
\hline \multirow[t]{2}{*}{ L_PA } & PRE & POST & 1.271 & 6.329 & $* *$ & \multirow{2}{*}{ REJECTED } \\
\hline & & POST2 & 0.289 & & & \\
\hline \multirow[t]{2}{*}{$C_{-} F$} & PRE & POST & 1.366 & 6.207 & $k \geqslant$ & \multirow{2}{*}{ REJECTED } \\
\hline & & POST2 & 0.978 & & & \\
\hline \multirow[t]{2}{*}{ C_so } & PRE & POST & 0.990 & 5.712 & $\geqslant *$ & \multirow{2}{*}{ REJECTED } \\
\hline & & POST2 & -0.033 & & & \\
\hline \multirow[t]{2}{*}{ SO_L } & PRE & PRE & 0.866 & 4.099 & $*$ & \multirow{2}{*}{ REJECTED } \\
\hline & & POST2 & 0,278 & & & \\
\hline
\end{tabular}

"significance at the 10\% level; "** significance at the $5 \%$ level. + A Welch test was used instead of ANOVA to test hypotheses based on a heteroscedasticity analysis; however, the results are very similar in this case.

Source: Authors' own.

Table 3 evidences the conclusions mentioned above for the high deviation between expectations and perception in communication with public administrations and other stakeholders such as funders and society. This denotes that the expectation created is higher than perception, increasing further following the integration of social accounting over time, in the implementation process, which predicts that although there are barriers, it can be used for its proposed purpose. 


\section{Segmented analysis: typology, size and position}

As seen in the sample, companies vary in terms of their legal format, province, number of employees, and also in the position of the person responsible for completing the questionnaire. We therefore conducted a segregated analysis regarding the average responses of the two questionnaires, as we do not have enough responses for questionnaire three for segregation.

Starting with the sector, we categorized the entities into five blocks: special employment centers, cooperative groups, museums (which are normally foundations), NGOs and mutual holdings. Observing the means per sector, we can determine that cooperative groups have the highest expectations in terms of communication, with a mean of seven out of seven, followed by mutual holdings, with a mean of six point five out of seven. However, there are no significant differences. In terms of strategy, special employment centers and NGOs have the highest expectations, as they are companies with a real social purpose. As for the results, there are no significant differences (see Figure6).

If we observe the variation between the first and second questionnaire, cooperatives and mutual holdings present the sharpest decreases in all three blocks, while NGOs and Special employment center represent the smallest variations between expectations and perceptions.

\section{Figure 6. Means per typology}

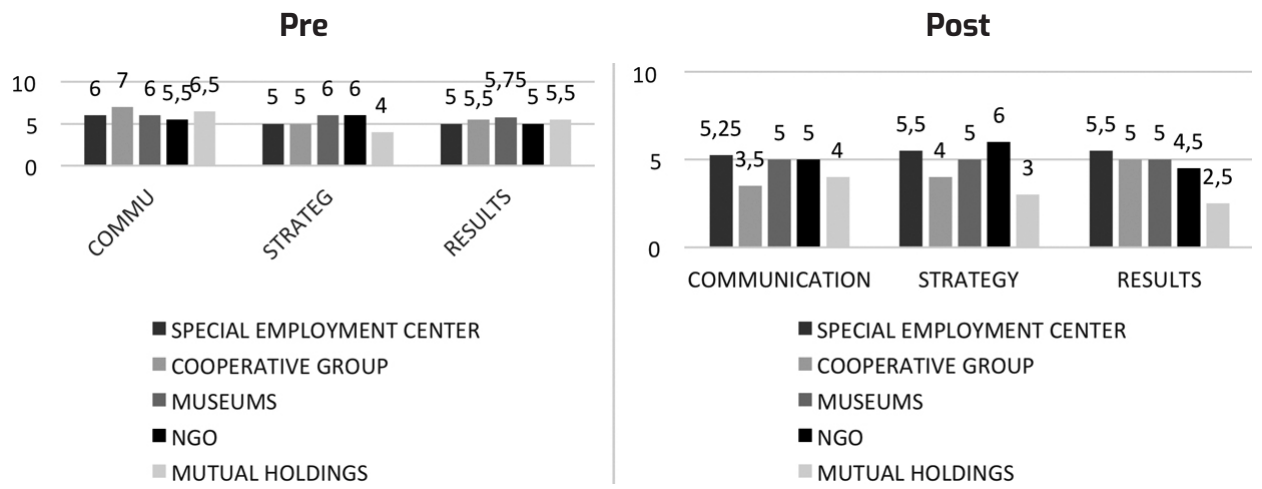

Source: Authors' own based on results from SPSS.

If we segregate the responses by company size, taking into account the number of employees each company has, we observe that companies with 11 to 100 employees have lower expectations, although there are no differences with the answers in the second questionnaire (see Figure 7). 
Figure 7. Means per size
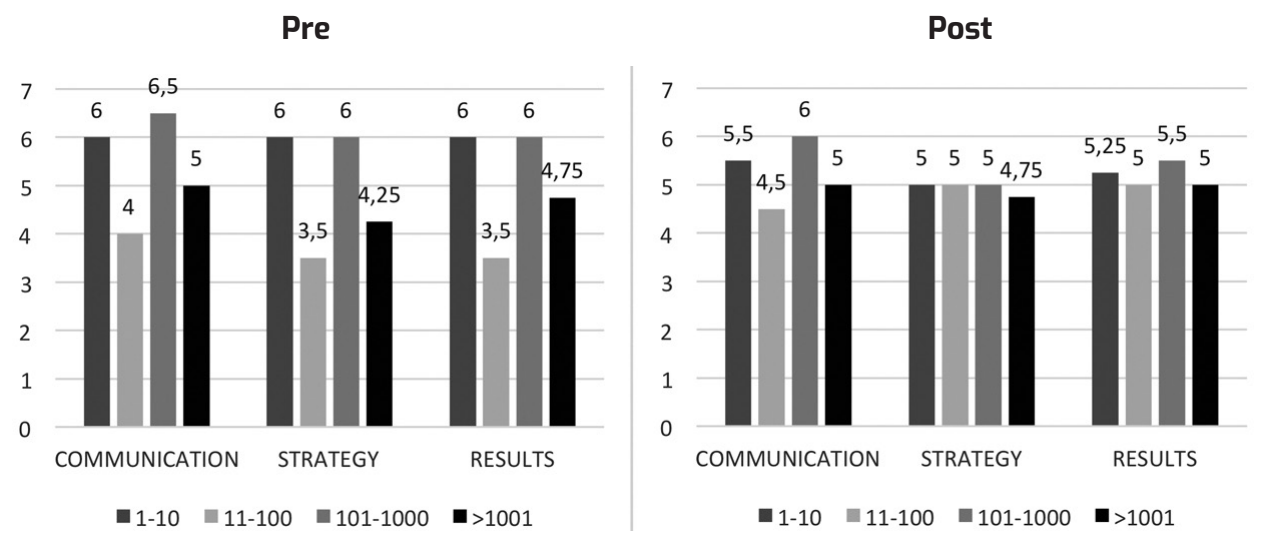

Source: Authors' own based on results from SPSS.

Those responsible for completing the questionnaires were categorized as CEOs, covering directors and managers, financial managers and others. This latter category included a quality and a marketing manager. Analyzing the answers, and despite the lack of significant differences, we were able to determine that the CEOs and financial managers have higher expectations in terms of communication and the other managers for results. Managers' perceptions remain unchanged following social accounting (See Figure 8).

\section{Figure 8. Mean results by position}

\section{Pre}

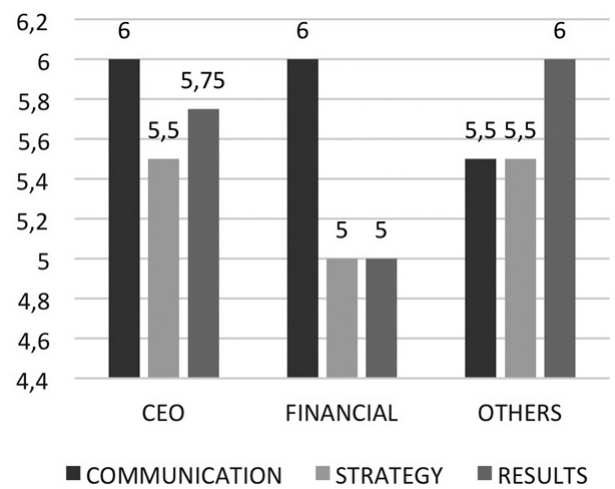

Post

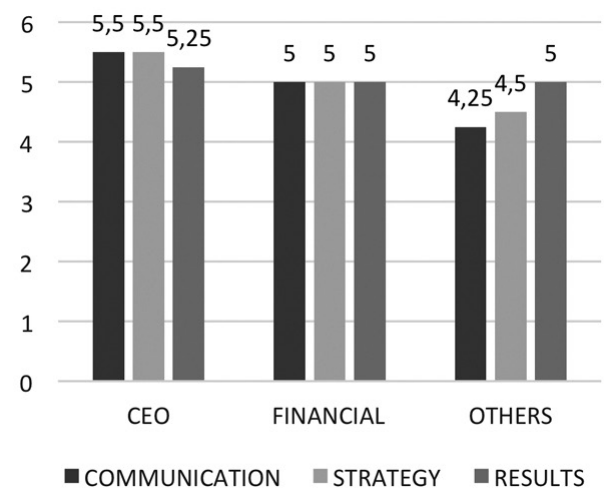

Source: Authors' own based on results from SPSS. 
To conclude with the segregated analysis, we did not observe any significant differences in terms of company size or the manager answering the questionnaire. There are some differences by legal format, which leads us to think that social accounting better fulfills its function in entities whose object is closer to society.

\section{Success Factors based on Lewin's Driving Forces}

Lewin's work was based on a strong moral and ethical belief in the importance of democratic institutions and democratic values in society, as social companies are committed to carry out. As seen in the segregated analysis per typology, companies which are more committed to society present smaller variations between expectations and perceptions and are more satisfied overall.

Lewin also saw behavioral change as a slow process, a trend that we observed in the integration and implementation of social accounting. This is summarized in the Figure 9, which shows that successful change in companies only starts some time following the implementation of social accounting, generally some six months after.

\section{Figure 9. Lewin's Driving Forces from the social economy for the suc- cessful implementation of social accounting}

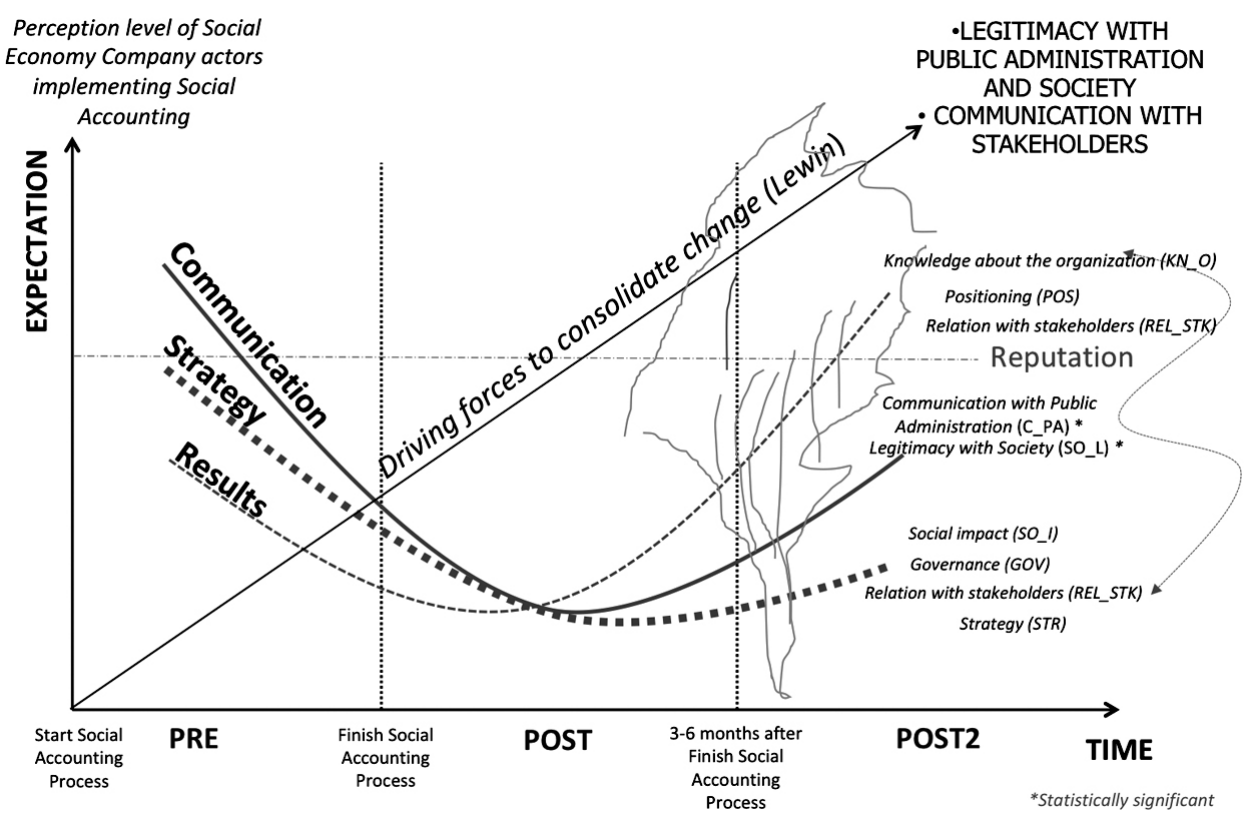

Source: Authors' own. 
The variables were analyzed at three moments (prior to implementation, immediately following implementation and sometime after) and on three different levels; communication, strategy and results. The perceptions about analyzed aspects are high at the beginning, but at the end, they are considerably lower and require some time to recover. The most important aspects are shown in the figure: namely how reputation is the most successful factor in implementing implement social accounting, although other factors, such as communication with public administrations and stakeholders are relevant and necessary as successful determinants. Strategies and results are positively valued by social economies when they implement social accounting, but knowledge and information about the social value of the company is the main result with which "real" change begins. The consolidation of change, which allows for the successful implementation of social accounting, will be forced by reputation and communication with agents (public administrations and stakeholders). Various key issues also emerge at each level of analysis: communication legitimacy with society and communication with public administrations; the social impact of strategy, governance, relations with stakeholders and strategy system as competency element; and knowledge about the organization, positioning and relations with stakeholders.

Strategies such as social impact, governance or relationship with stakeholders are therefore responsible for bringing about successful change. Individuals' perceptions are important, of course, and they will influence the group, but it is important to show society results in terms of the communication, information and reputation about the social aspects of companies. This all further underpins Lewin's theory regarding the need not only to implement new change processes, such as social accounting, but also to analyze the driving forces to push and achieve a consolidated change; in this case, the social value purpose of the social economy. Moreover, more time is needed to consolidate change, and some driving and restraining forces should be taken into account in order to secure this.

\section{Conclusion and implications}

The aim of our research was to determine the success factors or principal positive change driving factors in social companies in the implementation of social accounting. A further objective was to contribute to Lewin's change theory by analyzing the driving force behind change. A quantitative study was conducted in order to confirm the results obtained in a previous qualitative analysis and highlight the main factors that secure the successful implementation of the social accounting. A questionnaire was distributed in order to collect the perception of managers in Spanish social economy organizations where social accounting was calculated with the aim to analyze the change process in social companies. The questionnaire was divided into three blocks that reflect the main levels of the change process: communication, strategy and results. When attempting to change individual perceptions, it is important for companies to analyze the underlying forces in order to guarantee optimum results. This analysis will reveal the key factors for the successful implementation of social accounting. 
Companies start social accounting with a reputational objective and with high expectations of improvement, especially in terms of learning, transparency and the reinforcement of social commitment. Throughout the implementation process, and until the total integration of social accounting in the company, employees perceive that these aspects improve the level of initial expectations. However, managers perceive that other aspects, such as improved networking, evolve positively throughout the process of integrating social accounting.

On the other hand, managers' expectations regarding improvements in communication, strategy and results vary depending on the size of the company and the profile of the manager responding to the questionnaire, although later relevant variations in perceptions are not appreciated. The typology of company does seem to be a determining variable both in the generation of expectations and in the perceptions collected at the end of the process of implementing social accounting.

Levels of change are considered in the implementation of any system; namely communication, strategy and result. Although reputation is the main factor that forces the organization to integrate the social accounting, the success factors are essentially three: legitimacy with public administrations, legitimacy with society and communication with stakeholders. They are attractive factors for measuring the degree of implementation of social accounting, and are at least the most relevant for managers. Efficient and competitive change will come only when those factors are not only expectations, but also a form of satisfaction for the managers that implement and integrate the social accounting in Spanish social economy companies.

This study involves several implications concerning social accounting for enterprises of the social economy. It provides some explanation for the driving forces necessary to achieve successful change when implementing social accounting. These findings the managers of social economy companies to focus on providing tools or knowledge through training employees in social accounting to integrate social accounting into the improvement of strategy, and developing social communication plans immediately after the implementation of the social accounting. Nonetheless, social accounting also offers the opportunity for social economy organizations to reconsider their relationships with stakeholders in order to improve their social commitment and social impact. For staff, there is a clear opportunity to further and consolidate their commitment to the company. Finally, social accounting is perceived as a promoter of networking between companies in the same sector, as it offers the opportunity to share and compare their results with other companies. In short, those expectations - reputation, improving social impact, relationship with stakeholders and communication with public administration and stakeholders - will be the pre-requisites, understood as the driving forces that make the implementation of social accounting successful.

Our study has a number of limitations. One of these is its relatively small size. The lack of tools and knowledge regarding integrated social accounting and the length of time involved in its implementations explain the low number of responses in the third survey. The results of this study suggest that driving forces of social accounting are accrued in the long-term. Most of the companies included in our universe are foundations, contributing probably to a distorted vision of the change factors, which should also be examined through the opinions of other 
types of enterprises. Lewin's theory is criticized as simplistic; and this study also fails to explain the experience of those involved. Therefore, the results must be interpreted with caution.

Future research could focus on a wider range of enterprises with productive activity. Future research may further examine expected as opposed to actual benefits derived from the application of social accounting, and those restraining forces that balance the change process and make a wide-ranging contribution.

\section{References}

AGUILERA, R.V., RUPP, D.E., WILLIAMS, C.A. \& GANAPATHI, J. (2007): "Putting the S back in corporate social responsibility: a multi level theory of social change in organizations", Academy of Management Review, 32(3), 836-863. https://psycnet.apa.org/doi/10.2307/20159338.

ALLPORT, G.W. (1948): Foreword. In Lewin, G.W. (Ed.), Resolving Social Conflict. Harper \& Row.

BARGAL, D. \& BAR, H. (1992): "A Lewinian approach to intergroup workshops for Arab-Palestinian and Jewish Youth", Journal of Social Issues, 48(2), 139-54.

https://doi.org/10.1111/j.1540-4560.1992.tb00889.x.

BROCCARDO, L. \& ZICARI, A. (2020): "Sustainability as a driver for value creation: A business model analysis of small and medium entreprises in the Italian wine sector", Journal of Cleaner Production 2020, 259, 120852. https://doi.org/10.1016/j.jclepro.2020.120852.

CHAVES, R. \& MONZÓN, J.L. (2018): "La economía social ante los paradigmas económicos emergentes: innovación social, economía colaborativa, economía circular, responsabilidad social empresarial, economía del bien común, empresa social y economía solidaria", CIRIEC-España Revista de Economía Pública, Social y Cooperativa, 93, 5-50.

https://doi.org/10.7203/CIRIEC-E.93.12901.

ERNST \& YOUNG. (2019): Rethinking Sustainability Estudio Comparativo de los Estados de Información No Financiera (EINF) del IBEX 35. https://www.ey.com/Publication/vwLUAssets/ ey-rethinking-sustainability-estudio-comparativo-de-los-estados-de-informacion-no-financiera-del-ibex-35/\$FILE/ey-rethinking-sustainability-estudio-comparativo-de-los-estados-de-informacion-no-financiera-del-ibex-35.pdf

ETXEZARRETA, E.E., DE MENDIGUREN CASTRESANA, J.C.P., MOLINA, L.D. \& AMOZARRAIN, A. E. (2018): "Valor social de las cooperativas sociales: aplicación del modelo poliédrico en la cooperativa para la acogida de menores Zabalduz S. Coop", CIRIEC-España, Revista de Economía Pública, Social y Cooperativa, (93), 155-180. https://doi.org/10.7203/CIRIEC-E.93.9953

FREEMAN, R.E. (1984): Strategic Management: A Stakeholder Approach, Pitman. 
FRENCH, W. \& BELL, C. (1984): Organization development: behavioral science interventions for organization improvement, Pearson edition.

GRAY, R. (2002): "The social accounting project and Accounting Organizations and Society Privileging engagement, imaginings, new accountings and pragmatism over critique?", Accounting, Organizations and Society, 27(7), 687-708. https://doi.org/10.1016/S0361-3682(00)00003-9.

KIPPENBERGER, T. (1998): Planned change: Kurt Lewin's legacy. The Antidote, 14, 10-12. https://doi.org/10.1108/EUM0000000006617.

HARRISON, J.S., PHILLIPS, R.A. \& FREEMAN, R.E. (2020): “On the 2019 Business Roundtable "Statement on the Purpose of a Corporation". Journal of Management, 46(7), 1223-1237. https://doi.org/10.1177\%2F0149206319892669.

LAZKANO, L., SAN-JOSE, L. \& RETOLAZA, J.L. (2019): "Social accounting in the social economy: a case study of monetizing social value". In: Modernization and accountability in the social economy sector (pp. 132-150). IGI Global. http://doi:10.4018/978-1-5225-8482-7.ch008.

LAZKANO, L. \& SAN-JOSE, L. (2019): “Monetización del valor social: el caso Clade”, Revista Vasca de Economía Social, 2019, 16, 103-127. https://doi.org/10.1387/reves.20903.

LENSSEN, G., TYSON, S., PICKARD, S., BEVAN, D., CASTELLÓ, I. \& LOZANO, J. (2009): “From risk management to citizenship corporate social responsibility: analysis of strategic drivers of change", Corporate Governance: The international journal of business in society, 9(4), 373-385. https://doi.org/10.1108/14720700910984927.

LEWIN, K. (1947): “Frontiers in group dynamics”. In Cartwright, D. (Ed.), Field Theory in Social Science. Social Science Paperbacks. https://doi.org/10.1177\%2F001872674700100103.

LEWIN, K. (1947b): Group Decision and Social Change. Editorial Committee, Henry Holt and Co.

LEWIN, K. (1951): Field Theory in Social Science, Harper \& Row. https://doi.org/10.1177\%2F000271625127600135.

LEWIS, L. (1999): "Disseminating information and soliciting input during planned organizational change: implementers' targets, sources and channels for communicating", Management Communication Quarterly, 13(1), 43-75. https://doi.org/10.1177\%2F0893318999131002

MAON, F., LINDGREEN, A. \& SWAEN, V. (2009): "Designing and implementing corporate social responsibility: An integrative framework grounded in theory and practice", Journal of Business Ethics, 87(1), 71-89. https://doi.org/10.1177\%2F0893318999131002.

MONGE, P. \& POOLE, M. S. (2008): "The evolution of organizational communication", Journal of Communication, 58(4), 679-692. https://doi.org/10.1111/j.1460-2466.2008.00408.x. 
RESTAKIS, J. (January 2006): “Defining the Social Economy-The BC Context”, BC Social Economy Roundtable. British Columbia Co-operative Association.

https://ccednet-rcdec.ca/sites/ccednet-rcdec.ca/files/restakis_definingsocialeconomy.pdf

RETOLAZA, J.L. \& SAN-JOSE, L. (2018): “Contabilidad social para el bien común”, Revista de Responsabilidad Social de la Empresa, 29, 95-122.

RETOLAZA, J.L., SAN-JOSE, L. \& RUIZ-ROQUEÑI, M. (2015): “Monetarizing the social value: theory and evidence", CIRIEC-España, Revista de Economía Pública, Social y Cooperativa, 83, 43-62.

RETOLAZA, J.L., SAN-JOSE, L., RUIZ-ROQUEÑI, M. (2016): Social Accounting for Sustainability. Monetizing the Social Value, Sringer publishing. https://doi.org/10.1007/978-3-319-13377-5

SAN-JOSE, L. \& RETOLAZA, J.L. (2016): Contabilidad Social orientada a los stakeholders. Perspectiva de la Administración Pública, Pirámide.

SAN-JOSE, L., MENDIZABAL, X. \& RETOLAZA, J.L. (2020): "Social Accounting and Business Legitimacy". In J.D. Rendtorff (ed.), Handbook of Business Legitimacy. Cham: Springer. https://doi.org/10.1007/978-3-319-68845-9_88-1.

SPATHIS, C. \& ANANIADIS, J. (2005): "Assessing the benefits of using an enterprise system in accounting information and management", The Journal of Enterprise Information Management, 18(2), 195-210. https://doi.org/10.1108/17410390510579918.

TITO, P. (2003): “Importancia del desarrollo estratégico para el planteamiento organizacional. Gestión en el Tercer Milenio", Revista investigación Ciencias Administrativas, UNMSM, 5(10). https://doi.org/10.15381/gtm.v5i10.9927.

VELAMURI, S.R., PRIYA, A. \& VASANTHA, K. (2015): “Doing Well to Do Good: Business Model Innovation for Social Healthcare", Business Models and Modelling (Advances in Strategic Management, 33, 279-308. 


\section{Annexes}

\section{Annex 1. Questionnaire.}

COMMUNICATION

\begin{tabular}{|c|c|}
\hline 1. Improve communication with Public Administrations & C_PA \\
\hline 2. Improve legitimacy with Public Administrations & L_PA \\
\hline 3. Improve communication with Funders & C_F \\
\hline 4. Improve communication with Partners / Shareholders & C_SHA \\
\hline 5. Improve communication with Users / Clients & C_CLI \\
\hline 6. Improve communication with the Society & C_so \\
\hline 7. Improve Social legitimacy & SO_L \\
\hline 8. Improve the preparation of social responsibility reports & REPORT \\
\hline 9. Improve workers satisfaction & WORK_S \\
\hline 10. Improve the reputation of the organization & REPUT \\
\hline \multicolumn{2}{|l|}{ STRATEGY } \\
\hline 11. Improve the strategy & STR \\
\hline 12. Improve operational management & O_M \\
\hline 13. Improve management quality & M_Q \\
\hline 14. Improve the quality of the service / product & Q_S/P \\
\hline 15. Improve Social Impact & SO_l \\
\hline 16. Improve shared value management & SVM \\
\hline 17. Reduce conflicts of interest between stakeholders & CON_I \\
\hline 18. Improve governance & GOV \\
\hline 19. Improve the economic results of the entity & $E C \_R$ \\
\hline 20. Improve the relationship with stakeholders & REL_STK \\
\hline \multicolumn{2}{|l|}{ RESULTS } \\
\hline 21. Improve knowledge about the organization & KN_O \\
\hline 22. Improve continuous learning & C_L \\
\hline 23. Improve positioning & POS \\
\hline
\end{tabular}




\begin{tabular}{ll}
\hline 24. Reduce social risk & SO_R \\
\hline 25. Improve worker motivation & WRK_M \\
\hline 26. Improve the purpose & PURP \\
\hline 27. Improve transparency & TRNS \\
\hline 28. Improve sustainability & SUST \\
\hline 29. Align the interests of the stakeholders & INT_STK \\
\hline 30. Reinforce social commitment & SO_C \\
\hline 31. Increase resources & INC_R \\
\hline 32. Improve networking & NET \\
\hline
\end{tabular}

Source: Authors' own. 